\title{
Article \\ Experimental Evaluation of Recycled Aggregates, Washing Water and Cement Sludge Recovered from Returned Concrete
}

\author{
Alessandra Diotti *(D), Luca Cominoli, Giovanni Plizzari and Sabrina Sorlini \\ Department of Civil Engineering, Architecture, Land, Environment and Mathematics, University of Brescia, \\ 25123 Brescia, Italy; luca.cominoli@unibs.it (L.C.); giovanni.plizzari@unibs.it (G.P.); sabrina.sorlini@unibs.it (S.S.) \\ * Correspondence: a.diotti@unibs.it
}

check for updates

Citation: Diotti, A.; Cominoli, L.; Plizzari, G.; Sorlini, S. Experimental Evaluation of Recycled Aggregates, Washing Water and Cement Sludge Recovered from Returned Concrete. Appl. Sci. 2022, 12, 36. https:// doi.org/10.3390/app12010036

Academic Editor: Jie Xu

Received: 1 December 2021

Accepted: 20 December 2021

Published: 21 December 2021

Publisher's Note: MDPI stays neutral with regard to jurisdictional claims in published maps and institutional affiliations.

Copyright: (c) 2021 by the authors. Licensee MDPI, Basel, Switzerland. This article is an open access article distributed under the terms and conditions of the Creative Commons Attribution (CC BY) license (https:// creativecommons.org/licenses/by/ $4.0 /)$.

\begin{abstract}
In this paper, a new innovative technology for the treatment of returned concrete is proposed. This method is based on the application of physical-mechanical processes that allow to obtain new quality products: recycled aggregates, microfiltered water and cement sludge. Specifically, by means of a mechanical system equipped with buffer and Archimedes screws, fine $(\mathrm{d}<5 \mathrm{~mm})$ and coarse $(\mathrm{d}>5 \mathrm{~mm})$ aggregates are obtained. The water coming from the washing process is sent to a microfiltration process, where a filter membrane separates the liquid phase (microfiltered water) from the solid phase (cement sludge) and no type of potentially toxic additive is added. In this context, this paper investigates the feasibility of using all these components as new raw materials for sustainable concrete production. In particular, according to the requirements imposed by technical standards, an experimental program was developed, aimed at evaluating the physical, chemical, and mechanical properties of the analyzed materials. The results showed that both recycled aggregates, the microfiltered water and the cement sludge can be used to produce new structural concrete. In particular, it was proven that also the cement sludge, which generally represents the most critical component destined for disposal, can be reused as filler in the partial replacement of sand.
\end{abstract}

Keywords: returned concrete; recycled aggregates; washing water; sludge; circular economy; ready-mixed concrete plant

\section{Introduction}

In 2019, 28.4 million cubic meters of concrete were produced in Italy [1]. According to the ERMCO Report [2] and Ferrari et al. [3], in European industrialized countries, approximately $2-3 \%$ of the concrete produced returns to the batching plants at the end of the day. Based on this estimate, the returned concrete produced in Italy consists of approximately 710,000 cubic meters per year. Considering that aggregates constitute approximately 80 percent of the total volume of concrete [4,5], about 1.6 million tons of recycled aggregates could come from the recovery of returned concrete.

The use of recycled materials in the construction sector can lead to several environmental benefits, including sustainable natural resources conservation, less waste disposal in landfills and, finally, the obtaining of new alternative materials capable of totally or partially replacing virgin raw materials [6,7]. In particular, there are many recycled materials that can be used in construction (e.g., construction and demolition waste, supplementary cementitious materials, geopolymers, steel slags and much more). The recycled aggregates obtained from the treatment of construction and demolition wastes, especially those deriving from concrete fractions, are valid substitutes for natural aggregates in concrete mixtures and in engineering works [8-10]. However, it is necessary to take some precautions, as, compared to natural aggregates, recycled aggregates show lower physical-mechanical performance [11,12]. In particular, as stated by Verian et al. [9], contaminants and adhered mortar in the recycled aggregates should be minimized and their use kept to a limited percentage (30\%). This limit, however, can be increased (i.e., 50\% and 100\%) if the mix design, batching methodology and the moisture conditions of the recycled concrete aggregates are 
properly managed. Moreover, the use of supplementary cementitious materials (SCMs), which have been shown to improve the quality of recycled concrete aggregate concrete, is also recommended.

As stated by Park et al. [13] and Juenger and Siddique [14], SCMs are commonly used in concrete mixtures to replace a portion of cement in concrete. This practice is industryfriendly, resulting in concrete with lower cost, lower environmental impact, higher longterm strength, and improved long-term durability. This is mainly due to the fact that the production of cement involves environmental pollution caused by dust and high energy consumption [15]. So, in order to reduce $\mathrm{CO}_{2}$ in the cement industry, high volumes of SCMs, such as ground granulated blast-furnace slag (GGBS), fly ash (FA), and/or silica fume (SF), are commonly blended with clinker to make Portland cement. At the same time, to minimize $\mathrm{CO}_{2}$ emissions, several studies evaluated the possibility of using geopolymers as alternative materials [16-19].

To date, the management of returned concrete is quite difficult for the concrete manufacturing industry. This is mainly due to the fact that the returned concrete is generally used on site to produce concrete blocks, whose deposit limits storage spaces of the batching plants. Therefore, companies sometimes need to transport part of the returned concrete to landfill to provide adequate storage spaces [20]. Sometimes the returned concrete can be also discharged into the batching plant for subsequent processing. The hardened discharged concrete is crushed and reused as a base for pavement or backfilling operations [21].

Regarding the potential recovery of returned concrete and its components, the literature presents several possibilities. In particular, depending on the type of treatment adopted, aggregates, washing water and cement sludge can potentially be recovered.

Ferrari et al. [22] converted the returned concrete in a granular material that can be used as recycled aggregate for concrete production. In particular, a superabsorbant polymer (SAP) is directly inserted into the truck mixer in a variable quantity $\left(0.4-0.8 \mathrm{~kg} \mathrm{SAP} / \mathrm{m}^{3}\right.$ of concrete, depending on water to cement ratio, type and dosage of cement and climate conditions) and, in a few minutes, the concrete is transformed into a granular material composed of an internal core, given by the original natural aggregate, covered by sand and hydrated cement paste. The properties of these new aggregates are related to the technical performance of the returned concrete, and, obviously, the mortar layer that surrounds the core of the new aggregates greatly influences their characteristics both in terms of size and other physical properties, such as lower density and higher water absorption values. Despite this, the hardened granular material can be used for the production of concrete, as partial substitute for the natural coarse aggregate. The results obtained by the authors indicated that concrete made with a replacement rate of 30\% guarantees mechanical performance similar to that of traditional concrete.

Bester et al. [23] with a similar procedure investigated the use of a two-component powder product based on polymers and inorganic compounds that can be mechanically mixed in the fresh returned concrete to separate fine and coarse aggregates. The aggregates obtained were used in concrete mixtures at replacement levels of $25 \%, 50 \%, 75 \%$ and $100 \%$. The results demonstrated that the use of both granulometric fractions (fine and coarse aggregate), regardless of the replacement ratio, do not affect the workability of the fresh concrete but lead to a reduction in compressive strength. In particular, the reduction in compressive strengths achieved at low levels of replacement is quite small (i.e., $25 \%$ replacement showed a compressive strength loss of less than 10\%). When the flexural strength is considered, the authors recorded an increase in the flexural strength of the concrete made, using coarse recycled aggregates and a very slight decrease in concrete made with the sand fraction.

Other studies evaluated the possibility of using washing water (composed of water, cement, and the thinnest part of aggregates) as mixing water for concrete production [24,25]. In this case, it is important to consider the quantity of fine solids that are introduced in the conglomerate, which can influence the mechanical performance of the final product [26]. In particular, Coppola et al. [27] studied the rheological and mechanical properties of 
concretes manufactured with washing water as a partial substitute of drinking water. Specifically, three different washing waters with solid residue amount in the range $0.13-5.5 \%$ by mass were used. The results showed that the content of fine solids in washing water does not cause anomalous air entrapping inside the concrete or significant modifications in the concrete specific weight. Conversely, the presence of fine particles drastically affects the workability of concrete. In particular, a significant loss of workability was recorded in concretes prepared with washing water, having a higher content of suspended solids, especially after $60 \mathrm{~min}$. This can lead to undesirable jobsite water additions.

In terms of compressive strength, the results highlighted that the lower content of fine particles guarantees mechanical performance similar to that of a traditional concrete. On the other hand, concretes prepared with waters with an abundant content of fine particles exhibited slightly higher compressive strength values at early ages. This can be ascribed to the improvement of the cement paste-aggregate interface. Same results were also obtained by other authors, such as Asadollahfardi et al. [28] and Ekolu and Dawneerangen [29].

As far as the cement sludge is concerned, Anastasiou et al. [30] evaluated the feasibility of using this component for the production of mortars with a cement replacement rate of $10 \%$ and $20 \%$ and as an additive for soil stabilization. The results showed that mortars made with dried and crushed cement slurry $(\mathrm{d}=75 \mu \mathrm{m})$, as a partial substitute for cement (10\% replacement), showed a compressive strength comparable to that of the mortar totally produced with Portland cement. Instead, the mortar with a replacement rate of $20 \%$ showed a 7\% strength reduction compared to the reference due to the high calcite content. As aforementioned, the cement sludge was also tested as an additive for soil stabilization, and two addition rates of sludge in soil were examined: $10 \%$ and $20 \%$. The results showed a significant increase in the California bearing ratio (CBR) value of the soils treated with cement sludge but a greater sensitivity to water variations compared to soils without cement sludge. However, the authors stated that this component can be used as a potential soil stabilization material.

In this context, the first goal of this paper is to propose a new innovative technology for the treatment of returned concrete that allows to obtain new quality products that can be reused in the production of concrete. In particular, by means of physical and mechanical processes, washed fine $(\mathrm{d} \leq 5 \mathrm{~mm})$ and coarse $(\mathrm{d} \geq 5 \mathrm{~mm})$ recycled aggregates, microfiltered water and cement sludge are produced. As stated above, the second goal is to investigate the technical and environmental feasibility of using these products as new raw materials for concrete production. To achieve this goal, several experimental tests are carried out on fine and coarse recycled aggregates (e.g., particle size distribution, particle density and water absorption, alkali-silica reactivity, water-soluble chloride content, acid-soluble sulphates, and leaching test), microfiltered water (e.g., suspended solids content, traces of oils, fats or detergents, chlorides, sulphates), cement sludge (e.g., moisture and dry matter content, isothermal conduction calorimetry test) and, finally, concrete mixtures (i.e., uniaxial compression strength and hygrometric shrinkage).

Given the high quality level, all these components can be used as new raw materials for concrete production. This permits significant environmental benefits, including the conservation of natural aggregates and the avoidance of further waste disposal in landfills. This technology is also easy to use, as it is directly installed at the batching plant.

The innovation of the proposed system is also related to its efficiency in terms of energy consumption. In fact, compared to a traditional recycling plant consisting of crushing, washing, and screening operations that consume over $6 \mathrm{kWh}$ of electricity per ton of treated material [31], the proposed solution allows for savings of over 10\% in terms of energy consumption $(5.5 \mathrm{kWh} / \mathrm{t})$.

In this context, in order to verify the effective quality of the components obtained downstream of the treatment process proposed in this study, their technical and environmental suitability is experimentally assessed according to the performance requirements imposed by technical regulations. 


\section{Innovative System for Returned Concrete Recovery}

In Italy, the fresh concrete returned to the batching plant is generally discharged into $1 \mathrm{~m}^{3}$ formwork, left to harden and subsequently used in low-resistance applications, such as road bollards, new jersey barriers, blocks for breakwaters or retaining walls. Usually, hardened concrete is also crushed and used to produce recycled aggregates for the construction sector [22].

The new method presented in this paper allows the recovery of fine and coarse aggregates, microfiltered water and cement sludge from the returned fresh concrete. In particular, the proposed process is carried out in dedicated treatment plants directly installed at the concrete mixing plants. The implemented concrete treatment plant consists of two main sections:

1. Treatment and recovery of the inert fraction contained in the returned concrete (Figure 1).

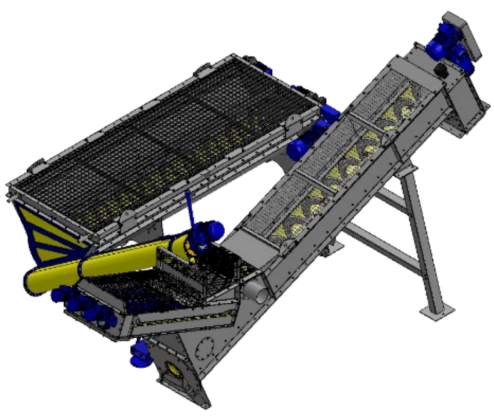

Figure 1. Treatment technology for inert fraction recovery. Mechanical system consisting of buffer and screws for the separation of fine aggregates $(\mathrm{d}<5 \mathrm{~mm})$ and coarse aggregates $(\mathrm{d}>5 \mathrm{~mm})$.

The process, by means of a mechanical system equipped with buffer and Archimedes screws, allows the recovery of fine aggregates with a particle diameter of less than $5 \mathrm{~mm}$ (sand) and coarse aggregates with a particle diameter higher than $5 \mathrm{~mm}$ (gravel). During the screening phase, each particle size fraction is also washed by means of a spray nozzle system. The washing water (which includes both the water used for washing the mixer truck and the resulting water from aggregate washing) is transported to an accumulation tank and subsequently sent to the microfiltration process. In particular, this water has a total suspended solids content of $97,455 \mathrm{mg} / \mathrm{L}$ ( $9.7 \%$ by mass).

2. Treatment and recovery of washing water (water and cement sludge) (Figure 2).
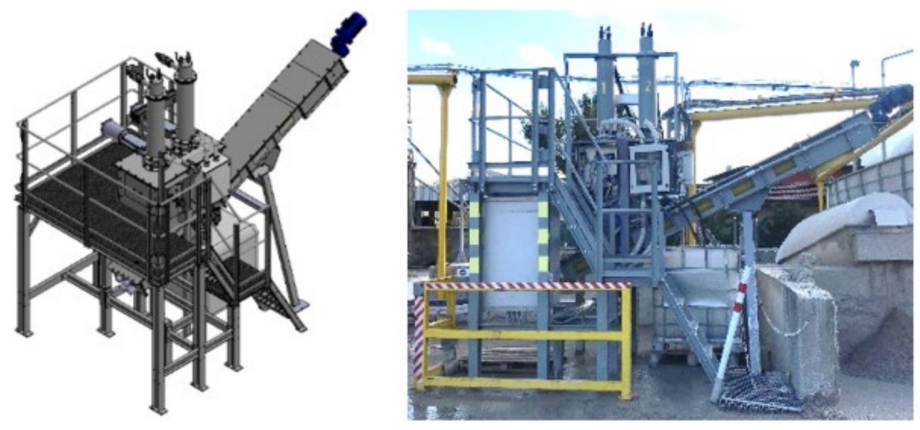

Figure 2. Treatment technology for washing water recovery. Mechanical system equipped with a filter membrane that separates microfiltered water and cement sludge.

The washing water coming from the mixer truck and aggregate washing process is, in the first phase, sent to an accumulation tank and kept stirred by mechanical agitators to avoid the sedimentation of the suspended solids. By means of a submerged pump, the water is subsequently sent to the microfiltration process, where a filter membrane with a porosity equal to $38 \mu \mathrm{m}$ separates the liquid phase (microfiltered water) from the solid phase (cement sludge). After that, the microfiltered water with a total suspended solids 
content of $22 \mathrm{mg} / \mathrm{L}$ (about $0.0001 \%$ by mass) is sent to a collection tank, while the cement sludge is discharged into a dedicated storage area.

In a context of environmental protection and circular economy, the proposed technology allows the total recovery of the returned concrete without generating waste and, at the same time, safeguarding the virgin raw materials, such as natural aggregates and water. Figure 3 illustrates the entire proposed treatment process.

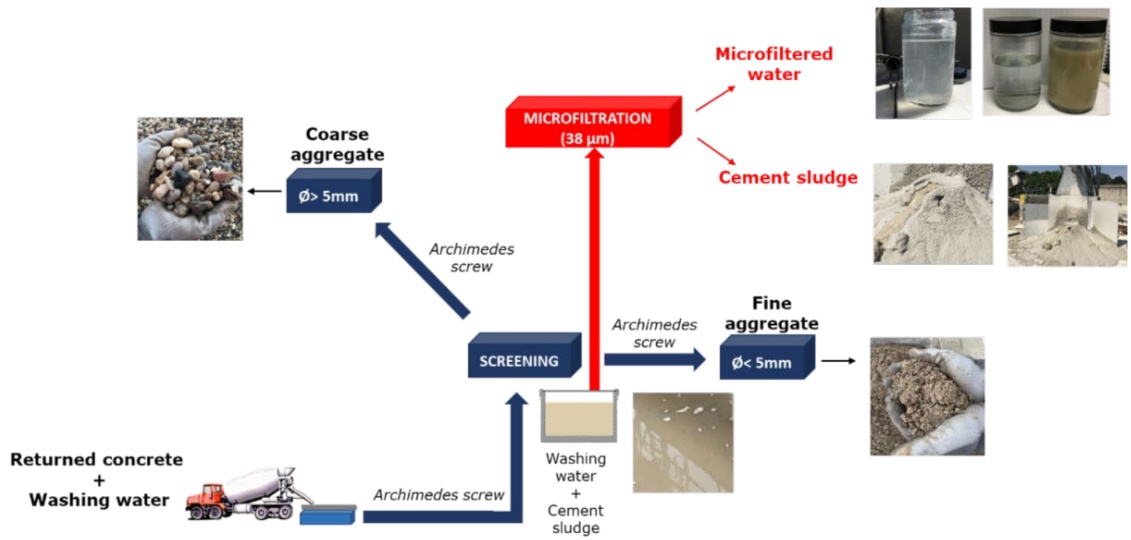

Figure 3. Proposed returned concrete treatment process. Section dedicated to the recovery of fine and coarse aggregates (blue zone) and section dedicated to the treatment of washing water to obtain microfiltered water and cement mud (red zone).

\section{Materials and Methods}

To assess the suitability of the products obtained by the returned concrete treatment process as new materials for concrete production, several experimental tests are carried out on fine and coarse aggregates, microfiltered water and cement sludge.

\subsection{Recycled Aggregates}

According to the geometrical, physical, and chemical requirements imposed by the technical standard UNI EN 12620, the inert fraction composed of fine aggregates $(\mathrm{d} \leq 5 \mathrm{~mm})$ and coarse aggregates $(\mathrm{d} \geq 5 \mathrm{~mm}$ ) was subjected to different experimental tests (Table 1 ). The main goal was to evaluate the feasibility of using recycled aggregates for new concrete production. At the same time, to evaluate the possible release of contaminants into the surrounding environment, the recycled aggregates were subjected to the leaching test according to the UNI EN 12457-2 standard $\left(\mathrm{d}_{\max } \leq 4 \mathrm{~mm}\right.$; liquid to solid ratio $=10 \mathrm{~L} / \mathrm{kg}$; contact time $24 \mathrm{~h}$; demineralized water). The eluate obtained was then chemically characterized in order to assess compliance with the limits imposed by Ministerial Decree 186/2006 for the recovery and reuse of non-hazardous waste.

Table 1. Experimental tests carried out on fine and coarse recycled aggregates.

\begin{tabular}{ccc}
\hline Experimental Test & Method & Type of Aggregate \\
\hline Particle size distribution & UNI EN 933-1,2 & Fine and coarse \\
Sand equivalent & UNI EN 933-8 & Fine \\
Methylene blue & UNI EN 933-9 & Fine \\
Particle density and water absorption & UNI EN 1097-6 & Fine and coarse \\
Alkali-silica reactivity & UNI EN 8520-22 & Fine and coarse \\
Water-soluble chloride content & UNI EN 1744-1 & Fine \\
Acid-soluble sulphates & UNI EN 1744-1 & Fine \\
Total sulfur content & UNI EN 1744-1 & Fine and coarse \\
Petrographic description & UNI EN 932-3 & Fine \\
Light organic impurities & UNI EN 1744-1 & Fine and coarse \\
Radioactivity & PRD 100 instrument & Fine and coarse
\end{tabular}




\subsection{Microfiltered Water and Cement Sludge}

The washing water, consisting of water and cement sludge, is classified as a liquid effluent, which can be destined for discharge or reuse. A possible alternative to the discharge is the reuse as mixing water to produce new concrete mixtures. In this context, the microfiltered water obtained downstream of the microfiltration process is characterized as new mixing water according to the requirements imposed by UNI EN 1008. In particular, the water must conform to the following:

1. Preliminary assessment tests to exclude traces of oils, fats or detergents, which can cause a reduction in concrete mechanical strength, as well as organic pollutants or acid substances, which can slow down the cement hydration;

2. Chemical requirements (chlorides, sulphates, alkalis, sugars, phosphates, nitrates, lead, zinc);

3. Requirements for setting time expected for specimens manufactured with both demineralized and analyzed water;

4. Requirements for compressive strength at 7 days expected for concrete or mortar specimens prepared with both demineralized and analyzed water.

The cement paste used to determine the initial and final setting time was obtained by mixing $500 \mathrm{~g}$ of Portland cement CEM II/A LL 42.5R with $125 \mathrm{~g}$ of water (demineralized and analyzed water). Subsequently, the two samples were placed in a truncated cone container with a height of $40 \pm 0.2 \mathrm{~mm}$ and subjected to Vicat needle penetration. Instead, the three normalized mortar samples $(40 \times 40 \times 160 \mathrm{~mm})$ used to determine the flexural and compressive strength were prepared using $1350 \mathrm{~g}$ of natural sand, $450 \mathrm{~g}$ of Portland cement and $270 \mathrm{~g}$ of water (demineralized and analyzed water).

The compressive strength was subsequently evaluated at 7 days. In particular, the load was applied and increased at a variable speed between $50 \mathrm{~N} / \mathrm{s}$ and $500 \mathrm{~N} / \mathrm{s}$ to reach the specimen failure in a time between $30 \mathrm{~s}$ and $90 \mathrm{~s}$. The average compressive strength $(\mathrm{Rm}, \mathrm{c})$ was then calculated as the ratio between the applied failure load $(\mathrm{N})$ and the cross-sectional area of the specimen $\left(\mathrm{mm}^{2}\right)$.

Regarding the cement sludge, a monitoring plan was prepared to assess its moisture and dry matter content. In particular, the sludge was collected from two sampling points within the microfiltration system (Figure 4), as they were considered representative for the use of sludge in concrete production.

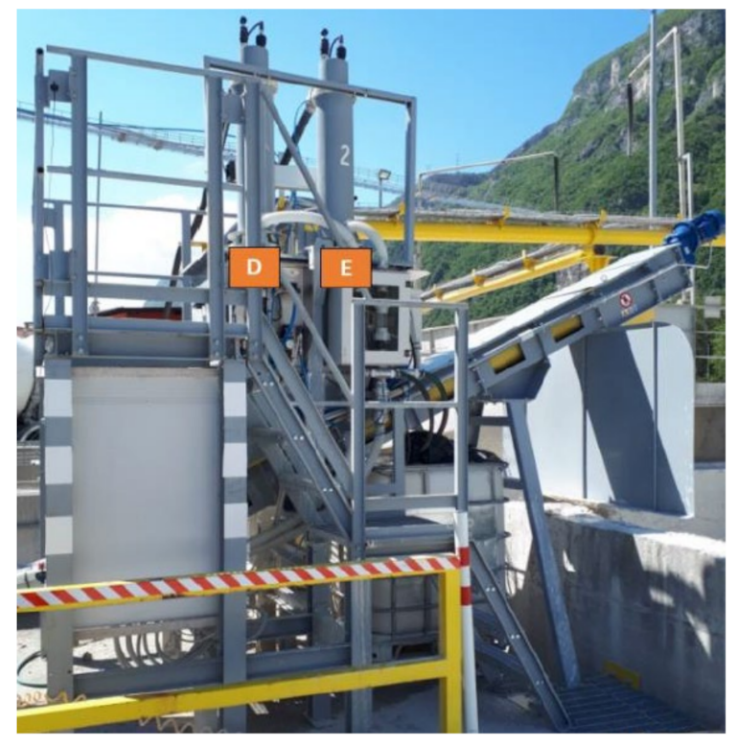

Figure 4. Cement sludge sampling points. 
The isothermal conduction calorimetry test (UNI EN 196-11) was also performed on the cement sludge in order to evaluate the possibility of using this component as a partial substitute of Portland cement in concrete mixtures. In particular, the main aim was to identify any residual hydration capacity of the sludge.

\subsection{Concrete Mixtures Made with Recycled Materials}

After the experimental characterization of the three main components produced by the treatment process, three concrete mixtures with strength grades of C10/15, C25/30 and C30/37 were prepared by combining recycled aggregates, microfiltered water and cement sludge with natural aggregates and drinking water. In particular, for each concrete grade the following mixtures were produced:

1. "Control mixture": 100\% natural aggregates and 100\% drinking water;

2. "50\% recycled mixture": $50 \%$ of recycled aggregates and 50\% of natural aggregates combined with $50 \%$ of microfiltered water and $50 \%$ of drinking water (no use of cement sludge);

3. "Cement sludge mixture": The same as the previous mixture (50\% recycled) but with the replacement of $50 \mathrm{~kg} / \mathrm{m}^{3}$ of natural sand with $50 \mathrm{~kg} / \mathrm{m}^{3}$ of cement sludge. As shown in Section 4.3, the cement sludge has no longer any residual hydration capacity, so the possibility of using sludge as filler (partial substitute of the fine natural aggregate) within the concrete mixture was evaluated.

Table 2 shows the composition of the three concrete mixtures.

Table 2. Concrete mix design.

\begin{tabular}{|c|c|c|c|}
\hline \multirow{2}{*}{ Component } & $\mathrm{C} 10 / 15$ & $\mathrm{C} 25 / 30$ & C30/37 \\
\hline & $\left(\mathrm{kg} / \mathrm{m}^{3}\right)$ & $\left(\mathrm{kg} / \mathrm{m}^{3}\right)$ & $\left(\mathrm{kg} / \mathrm{m}^{3}\right)$ \\
\hline Ordinary Portland cement ${ }^{1}$ & 220 & 310 & 360 \\
\hline Water & 140 & 177 & 178 \\
\hline Superplasticizer & 1.3 & 2.0 & 2.3 \\
\hline Fine aggregate $(0 / 7 \mathrm{~mm})$ & 1078 & 998 & 959 \\
\hline Medium aggregate $(7 / 15 \mathrm{~mm})$ & 333 & 320 & 320 \\
\hline Coarse aggregate $(15 / 31.5 \mathrm{~mm})$ & 549 & 565 & 551 \\
\hline $\mathrm{w} / \mathrm{c}$ ratio & 0.64 & 0.57 & 0.49 \\
\hline
\end{tabular}

${ }^{1}$ The cement type varies according to the concrete mixture considered: $32.5 \mathrm{R}$ for $\mathrm{C} 10 / 15$ and $42.5 \mathrm{R}$ for $\mathrm{C} 25 / 30$ and $\mathrm{C} 30 / 37$.

The concrete samples were stored in a fog room at a temperature of $20{ }^{\circ} \mathrm{C}$ and $95 \%$ relative humidity, and the uniaxial compression strength was evaluated on cubic samples $(1=150 \mathrm{~mm})$ at $3,7,14,21$ and 28 curing days, according to UNI EN 12390-3. The tests were carried out with the Controls Autocomp machine $(3000 \mathrm{kN})$ and a speed load of $0.6 \mathrm{MPa} / \mathrm{s}$.

Hygrometric shrinkage tests were also performed on prismatic samples $(400 \times 100$ $\times 100 \mathrm{~mm}$ ), stored in a moist room at $20{ }^{\circ} \mathrm{C}$ with $50 \%$ relative humidity, at $1,3,7,14$, 28,56 curing days, according to UNI EN 11307. In particular, for the relief of the surface shrinkage, the measurement points were positioned along a straight line laying on the two lateral surfaces of the specimen (opposite to that of the casting) and parallel to the principal axis. The distance between the locating pins $\left(\mathrm{L}_{\mathrm{s}, 0}\right)$ was equal to $300 \mathrm{~mm}$.

\section{Results and Discussion}

\subsection{Recycled Aggregates}

As stated by Ferrari et al. [22], the properties of the aggregates obtained from the recovery of returned concrete are strongly related to those of the original aggregates used in the initial concrete mixture.

The fine and coarse aggregates obtained by the proposed technology can be aesthetically compared to the original natural aggregates. This is mainly due to the fact that 
the returned fresh concrete is subjected to an efficient washing process that completely eliminates all the cement paste adhered to the original natural aggregate.

The experimental results obtained (Table 3) showed that, in terms of geometrical, physical, and chemical properties, the fine and coarse recycled aggregates comply with all the requirements imposed by the UNI EN 12620 and are, therefore, suitable for new concrete production. In particular, density values in the saturated-surface-dry condition (SSD) equal to $2720 \mathrm{~kg} / \mathrm{m}^{3}$ for both fine and coarse aggregates were recorded (values that fully comply with the minimum regulatory limit of $2300 \mathrm{~kg} / \mathrm{m}^{3}$ ). Compared to the density of natural aggregates (typically higher than $2600 \mathrm{~kg} / \mathrm{m}^{3}$ ) the density of the new aggregates is well aligned, while compared to recycled aggregates obtained from other returned concrete recovery processes, they show higher density. In particular, the aggregates produced by the method proposed by Ferrari et al. [22], which involves the use of a superabsorbent polymer capable of transforming the returned concrete into a new granular material, exhibit density values in the range of $2350 \mathrm{~kg} / \mathrm{m}^{3}$ and $2450 \mathrm{~kg} / \mathrm{m}^{3}$.

Table 3. Results of the experimental tests carried out on fine and coarse recycled aggregates.

\begin{tabular}{|c|c|c|c|c|}
\hline Experimental Test & U.M. & $\begin{array}{l}\text { Fine Recycled } \\
\text { Aggregate }\end{array}$ & $\begin{array}{c}\text { Coarse Recycled } \\
\text { Aggregate }\end{array}$ & $\begin{array}{l}\text { Limit of UNI } \\
\text { EN } 12620\end{array}$ \\
\hline Sand equivalent & - & 89 & - & $\geq 80$ \\
\hline Methylene blue & $(\mathrm{g} / \mathrm{kg})$ & 0.2 & - & $\overline{1} .5$ \\
\hline Particle density, SSD & $\left(\mathrm{kg} / \mathrm{m}^{3}\right)$ & 2720 & 2720 & $\geq 2300$ \\
\hline Water absorption & $(\%)$ & 1.1 & 0.8 & $1^{1}$ \\
\hline Alkali-silica reactivity & - & not reactive & not reactive & - \\
\hline Water-soluble chloride content & $(\%)$ & $<0.0012$ & - & 0.03 \\
\hline Acid-soluble sulphates & $(\%)$ & $<0.001$ & - & 0.2 \\
\hline Total sulfur content & $(\%)$ & $<0.001$ & - & 1 \\
\hline Petrographic description & - & \multicolumn{2}{|c|}{ continental deposits mainly consisting of carbonate rocks } & - \\
\hline Light organic impurities & $(\%)$ & 0 & - & 0.5 \\
\hline Radioactivity & $\left(\mathrm{CPM}^{2}\right)$ & absent & absent & absence of radioactivity \\
\hline
\end{tabular}

${ }^{1}$ Regulatory limit imposed for the coarse fraction only. ${ }^{2}$ Counts per minute (CPM).

In terms of water absorption (WA), the coarse aggregate highlights a WA value of $0.9 \%$ that complies with the maximum regulatory limit of $1 \%$ required for concretes operating in exposure class XF (freeze/thaw attack resistance). The presence of light organic impurities, radioactivity and alkali-silica reactivity is also not detected. Finally, the content of watersoluble chloride, acid-soluble sulphates and total sulfur is found to be lower than the respective regulatory limit.

Figure 5 shows the particle size comparison between the natural aggregates (NA) used to produce concrete and the recycled aggregates (RA) obtained by the proposed method.

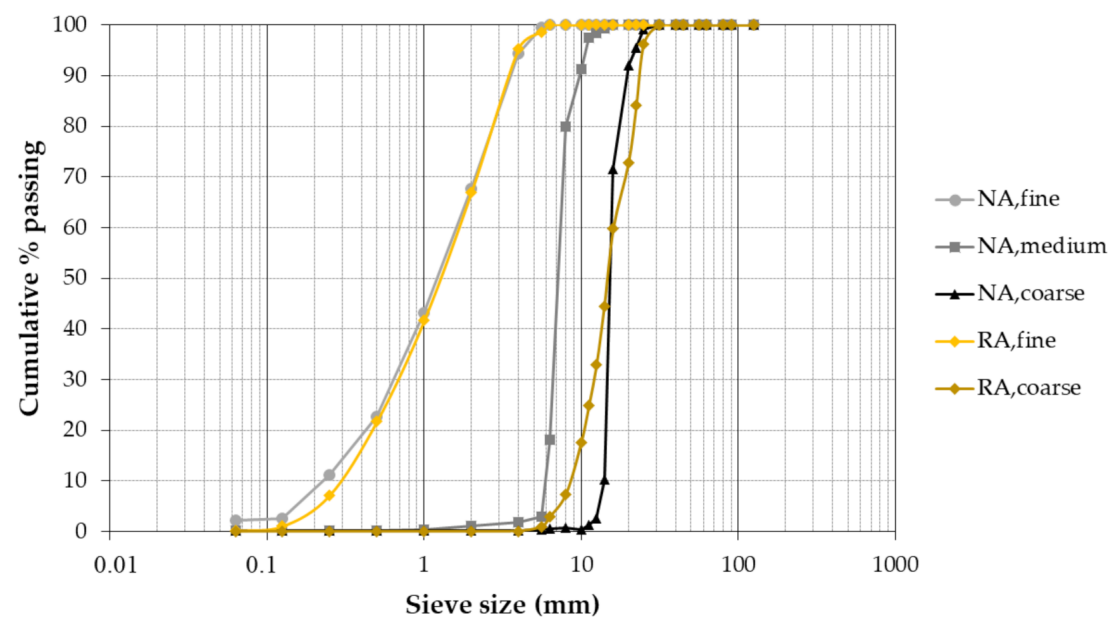

Figure 5. Particle size distribution of natural aggregates (NA) and recycled aggregates (RA). 
The comparison shows that the particle size distribution of the fine recycled aggregate is very similar to that of the fine natural aggregate. It has only a quantity of dust (diameter less than $0.250 \mathrm{~mm}$ and $0.125 \mathrm{~mm}$ ) slightly lower than the natural aggregate equal to $4 \%$ and $2 \%$, respectively. On the other hand, the coarse recycled aggregate shows a finer distribution up to $14 \mathrm{~mm}$ and a coarser one from $14 \mathrm{~mm}$ to $31.5 \mathrm{~mm}$. In fact, the natural aggregate passing at a sieve size of $14 \mathrm{~mm}$ is $10.2 \%$, while the recycled aggregate is $44.5 \%$.

Referring to the environmental behavior, the leaching test carried out on both fine and coarse aggregates shows pollutant release levels below the limits imposed by the M.D. 186/2006, as shown in Table 4.

Table 4. Leachate concentrations from fine and coarse recycled aggregates.

\begin{tabular}{ccccc}
\hline Parameter & U.M. & Fine Recycled Aggregate & Coarse Recycled Aggregate & Limit of M.D. 186/2006 \\
\hline pH & - & 12 & 10 & $5.5-12$ \\
Specific electrical conductivity & $(\mu \mathrm{S} / \mathrm{cm}$ & 2440 & 77 & - \\
Asbestos & $\mathrm{mg} / \mathrm{L}$ & $(* *)$ & $(* *)$ & 30 \\
Nitrates & $\mathrm{mg} / \mathrm{L}$ & $<1$ & $<1$ & 50 \\
Fluorides & $\mathrm{mg} / \mathrm{L}$ & 0.2 & 3 & 1.5 \\
Sulphates & $\mathrm{mg} / \mathrm{L}$ & 9 & $<1$ & 250 \\
Chlorides & $\mathrm{mg} / \mathrm{L}$ & $<1$ & $<5$ & 100 \\
Cyanides & $\mu \mathrm{g} / \mathrm{L}$ & $<5$ & 0.24 & 50 \\
Barium & $\mathrm{mg} / \mathrm{L}$ & $<.34$ & $<.01$ & 1 \\
Copper & $\mathrm{mg} / \mathrm{L}$ & $<0.01$ & $<0.05$ & 0.05 \\
Zinc & $\mathrm{mg} / \mathrm{L}$ & 0.06 & $<0.5$ & 3 \\
Beryllium & $\mu \mathrm{g} / \mathrm{L}$ & $<0.5$ & $<5$ & 10 \\
Cobalt & $\mu \mathrm{g} / \mathrm{L}$ & $<5$ & 250 \\
Nickel & $\mu \mathrm{g} / \mathrm{L}$ & $<2$ & $<5$ & 10 \\
Vanadium & $\mu \mathrm{g} / \mathrm{L}$ & $<5$ & $<1$ & 250 \\
Arsenic & $\mu \mathrm{g} / \mathrm{L}$ & $<1$ & $<0.5$ & 50 \\
Cadmium & $\mu \mathrm{g} / \mathrm{L}$ & $<0.5$ & $<5$ & 5 \\
Total chromium & $\mu \mathrm{g} / \mathrm{L}$ & 13 & $<1$ & 50 \\
Lead & $\mu \mathrm{g} / \mathrm{L}$ & 2 & $<1$ & 50 \\
Selenium & $\mu \mathrm{m} / \mathrm{L}$ & $<1$ & $<0.1$ & 10 \\
Mercury & $\mu \mathrm{g} / \mathrm{L}$ & $<0.1$ & $<5$ & 1 \\
COD & $\mathrm{mg} / \mathrm{L}$ & 8 & 30
\end{tabular}

$\left.{ }^{* *}\right)$ parameter not detectable as the filtration at $0.45 \mu \mathrm{m}$ as required by the UNI EN 12457-2 for the preparation of the eluate does not allow the passage of identifiable and measurable fibers with the current techniques in use (electron microscopy scanning with energy-dispersive X-ray spectrometry (EDS)).

The $\mathrm{pH}$ of both aggregates is found to be alkaline in the range 10-12. In particular, the $\mathrm{pH}$ value of the fine aggregate is equal to the maximum permissible regulatory limit of 12 .

\subsection{Washing Water}

The microfiltered water obtained by the treatment process is characterized as mixing water for new concrete production, according to UNI EN 1008. As stated above, the microfiltered water was subjected to: (1) preliminary evaluation tests, (2) analysis of the chemical properties, (3) evaluation of the cement paste setting times and, finally (4) evaluation of the compressive strength of the normalized mortar samples.

In this context, Table 5 shows the results related to the preliminary assessment tests and to the chemical properties of microfiltered water. In particular, the results demonstrate that the microfiltered water fully complies with all the limits imposed by the UNI EN 1008 standard. Specifically, the $\mathrm{pH}$ is strongly alkaline (12.8). As stated by Chatveera et al. [32], Su et al. [33], and Coppola et al. [27], this is probably due to the presence of residual cement particles in the water. 
Table 5. Results of the preliminary inspection of mixing water.

\begin{tabular}{|c|c|c|c|c|}
\hline & Parameter & U.M. & Microfiltered Water & Limit of UNI EN 1008 \\
\hline & Oil and fats & - & compliant & Not more than visible traces \\
\hline & Detergents & - & compliant & $\begin{array}{l}\text { Any foam should disappear } \\
\text { within } 2 \text { min }\end{array}$ \\
\hline & Color & - & compliant & Pale yellow or paler. \\
\hline & Suspended matter & - & compliant & $\begin{array}{l}\text { Estimated in water with } \\
\text { a density }>1.01 \mathrm{~kg} / \mathrm{L}\end{array}$ \\
\hline & Odor & - & compliant & $\begin{array}{c}\text { No smell, except the odour allowed for } \\
\text { potable water and a slight smell } \\
\text { of cement }\end{array}$ \\
\hline & Acids & - & 12.8 & $\mathrm{pH} \geq 4$ \\
\hline \multirow{4}{*}{ Chlorides } & Humic matter & - & compliant & $\begin{array}{l}\text { The colour shall be assessed } \\
\text { qualitatively as yellowish brown or } \\
\text { paler, after addition of } \mathrm{NaOH} \text {. }\end{array}$ \\
\hline & Prestressed concrete or grout & $\mathrm{mg} / \mathrm{L}$ & & 500 \\
\hline & $\begin{array}{l}\text { Concrete with reinforcement or } \\
\text { embedded metal }\end{array}$ & $\mathrm{mg} / \mathrm{L}$ & 18 & 1000 \\
\hline & $\begin{array}{l}\text { Concrete without reinforcement or } \\
\text { embedded meta }\end{array}$ & $\mathrm{mg} / \mathrm{L}$ & & 4500 \\
\hline Sulphates & & $\mathrm{mg} / \mathrm{L}$ & $<10$ & 2000 \\
\hline Alkali & & $\mathrm{mg} / \mathrm{L}$ & 747.8 & 1500 \\
\hline Sugars & & $\mathrm{mg} / \mathrm{L}$ & $<100$ & 100 \\
\hline Phosphates & & $\mathrm{mg} / \mathrm{L}$ & $<20$ & 100 \\
\hline Nitrates & & $\mathrm{mg} / \mathrm{L}$ & $<20$ & 500 \\
\hline Lead & & $\mathrm{mg} / \mathrm{L}$ & $<0.1$ & 100 \\
\hline Zinc & & $\mathrm{mg} / \mathrm{L}$ & $<0.1$ & 100 \\
\hline
\end{tabular}

The amount of chlorides and sulphates is within the required limits and these results confirm what other authors said [29].

The initial setting time obtained on specimens made with the water shall be not less than $1 \mathrm{~h}$ and not differ by more than $25 \%$ from the initial setting time obtained on specimens made with demineralized water. At the same time, the final setting time shall not exceed $12 \mathrm{~h}$ and not differ by more than $25 \%$ from the final setting time obtained on specimens made with demineralized water.

Table 6 shows the results obtained on the manufactured cement paste samples; both requirements are satisfied. In particular, the control mix achieved an initial setting time of $125 \mathrm{~min}$ and a final setting time of $280 \mathrm{~min}$, while samples containing microfiltered water had a slower setting time, giving initial and final setting times that are 20 and 15 min longer than those of the control mix, respectively. This may be due to the fact that microfiltered water still contains some small residual particles of cement which can increase the initial and final setting time. This can also be linked to the presence of particular cements (e.g., blast furnace cements containing blast furnace slag), which are known to increase the setting time of concretes for the same w/c ratio [29]. In fact, the returned concretes treated by the system can have different mix-design and, therefore, it is possible to hypothesize that sometimes different types of cement are used.

Table 6. Cement paste sample setting times.

\begin{tabular}{ccc}
\hline \multirow{2}{*}{ Parameter } & Demineralized Water Samples & Microfiltered Water Samples \\
\cline { 2 - 3 } & $(\mathbf{m i n})$ & $(\mathbf{m i n})$ \\
\hline Initial setting time & 125 & $145(+16 \%)$ \\
Final setting time & 280 & $295(+5.3 \%)$ \\
\hline
\end{tabular}

To verify the feasibility of using microfiltered water as mixing water, the last requirement to be respected concerns the compressive strength. The latter, as determined after 
7 days on mortar specimens prepared with the microfiltered water, must be at least $90 \%$ of the mean compressive strength of specimens prepared with demineralized water.

The results shown in Table 7 highlight that the average compressive strength of samples prepared with microfiltered water is $98 \%$ of the compressive strength provided by samples produced with control water. This demonstrates that the microfiltered water produced by the new treatment plant complies with all the performance requirements imposed by UNI EN 1008 and, therefore, can be used as mixing water for new concrete production.

Table 7. Compressive strength of mortar samples.

\begin{tabular}{cccccc}
\hline \multicolumn{2}{c}{ Mortar Sample } & Failure Load & Compressive Strength & Rm,c & Ratio, Rm,c \\
\hline \multirow{2}{*}{ Demineralized } & 1 & 32.70 & 19.51 & & \\
water samples & 2 & 31.03 & 19.39 & 19.42 & \\
& 3 & 30.97 & 19.35 & & \\
\hline \multirow{2}{*}{ Microfiltered } & 1 & 30.56 & 19.10 & & \\
water samples & 2 & 30.55 & 19.10 & 19.09 & $98 \%$ \\
& 3 & 30.52 & 10.07 & & \\
\hline
\end{tabular}

\subsection{Cement Sludge}

The cement sludge produced by the microfiltration process was subjected to a dry matter and moisture content assessment and, at the same time, to the assessment of any residual hydration capacity by means of an isothermal conduction calorimetry test. The moisture content in the cement sludge samples was found to be highly variable. In particular, the humidity variability range was $53-61 \%$.

Results from the isothermal conduction calorimetry test demonstrate that the cement sludge no longer has any hydration properties, even after reactivation with pozzolanic material; similar results were obtained by Anastasiou et al. [30].

In light of these results, in order to fully recover all the products obtained from the treatment process, the cement sludge was dried at $100^{\circ} \mathrm{C}$ to constant mass and subsequently used as filler in concrete mixtures.

\subsection{Concrete Made with Recycled Products}

In order to evaluate the mechanical behavior of concrete mixtures made with recycled aggregates, microfiltered water and sludge cement, several tests on hardened concrete were carried out.

\subsubsection{Compressive Strength}

Table 8 and Figure 6 show the comparison between the tested recycled concretes and the reference natural concretes for the considered resistance classes (C10/15, C25/30, and $\mathrm{C} 30 / 37)$.

Table 8. Compressive strength results at different curing time.

\begin{tabular}{|c|c|c|c|c|c|c|c|}
\hline \multirow[b]{2}{*}{ Mix } & \multirow{2}{*}{$\begin{array}{l}\text { Curing Time } \\
\text { (Days) }\end{array}$} & \multicolumn{2}{|c|}{ Control Mixture } & \multicolumn{2}{|c|}{ 50\% Recycled Mixture } & \multicolumn{2}{|c|}{ Cement Sludge Mix } \\
\hline & & $\begin{array}{l}\text { Density } \\
\left(\mathrm{kg} / \mathrm{m}^{3}\right)\end{array}$ & $\begin{array}{c}\text { Compr. } \\
\text { Strength (MPa) }\end{array}$ & $\begin{array}{l}\text { Density } \\
\left(\mathrm{kg} / \mathrm{m}^{3}\right)\end{array}$ & $\begin{array}{c}\text { Compr. } \\
\text { Strength (MPa) }\end{array}$ & $\begin{array}{l}\text { Density } \\
\left(\mathrm{kg} / \mathrm{m}^{3}\right)\end{array}$ & $\begin{array}{c}\text { Compr. } \\
\text { Strength (MPa) }\end{array}$ \\
\hline \multirow{5}{*}{ C10/15 } & 3 & 2345 & 15.13 & 2316 & 14.68 & 2301 & 13.50 \\
\hline & 7 & 2309 & 18.26 & 2340 & 18.10 & 2296 & 15.48 \\
\hline & 14 & 2317 & 19.41 & 2352 & 18.81 & 2303 & 16.74 \\
\hline & 21 & 2294 & 19.67 & 2331 & 19.65 & 2308 & 17.40 \\
\hline & 28 & 2370 & 20.20 & 2379 & $19.80(-2 \%)$ & 2314 & $17.53(-13 \%)$ \\
\hline
\end{tabular}


Table 8. Cont.

\begin{tabular}{|c|c|c|c|c|c|c|c|}
\hline \multirow[b]{2}{*}{ Mix } & \multirow{2}{*}{$\begin{array}{l}\text { Curing Time } \\
\text { (Days) }\end{array}$} & \multicolumn{2}{|c|}{ Control Mixture } & \multicolumn{2}{|c|}{$50 \%$ Recycled Mixture } & \multicolumn{2}{|c|}{ Cement Sludge Mix } \\
\hline & & $\begin{array}{l}\text { Density } \\
\left(\mathrm{kg} / \mathrm{m}^{3}\right)\end{array}$ & $\begin{array}{c}\text { Compr. } \\
\text { Strength (MPa) }\end{array}$ & $\begin{array}{l}\text { Density } \\
\left(\mathrm{kg} / \mathrm{m}^{3}\right)\end{array}$ & $\begin{array}{c}\text { Compr. } \\
\text { Strength (MPa) }\end{array}$ & $\begin{array}{l}\text { Density } \\
\left(\mathrm{kg} / \mathrm{m}^{3}\right)\end{array}$ & $\begin{array}{c}\text { Compr. } \\
\text { Strength (MPa) }\end{array}$ \\
\hline \multirow{5}{*}{$\mathrm{C} 25 / 30$} & 3 & 2355 & 21.88 & 2316 & 21.22 & 2288 & 19.31 \\
\hline & 7 & 2334 & 26.45 & 2343 & 25.54 & 2290 & 23.54 \\
\hline & 14 & 2311 & 29.58 & 2355 & 29.62 & 2291 & 26.35 \\
\hline & 21 & 2310 & 32.09 & 2317 & 31.50 & 2295 & 29.17 \\
\hline & 28 & 2353 & 34.17 & 2356 & $33.62(-1.6 \%)$ & 2302 & $31.78(-7 \%)$ \\
\hline \multirow{5}{*}{ C30/37 } & 3 & 2322 & 40.46 & 2276 & 39.65 & 2206 & 38.03 \\
\hline & 7 & 2341 & 45.37 & 2368 & 44.46 & 2224 & 42.64 \\
\hline & 14 & 2304 & 48.08 & 2273 & 47.12 & 2189 & 45.19 \\
\hline & 21 & 2328 & 49.44 & 2326 & 48.46 & 2211 & 45.97 \\
\hline & 28 & 2315 & 50.61 & 2283 & $49.59(-2 \%)$ & 2199 & $46.56(-7.9 \%)$ \\
\hline
\end{tabular}
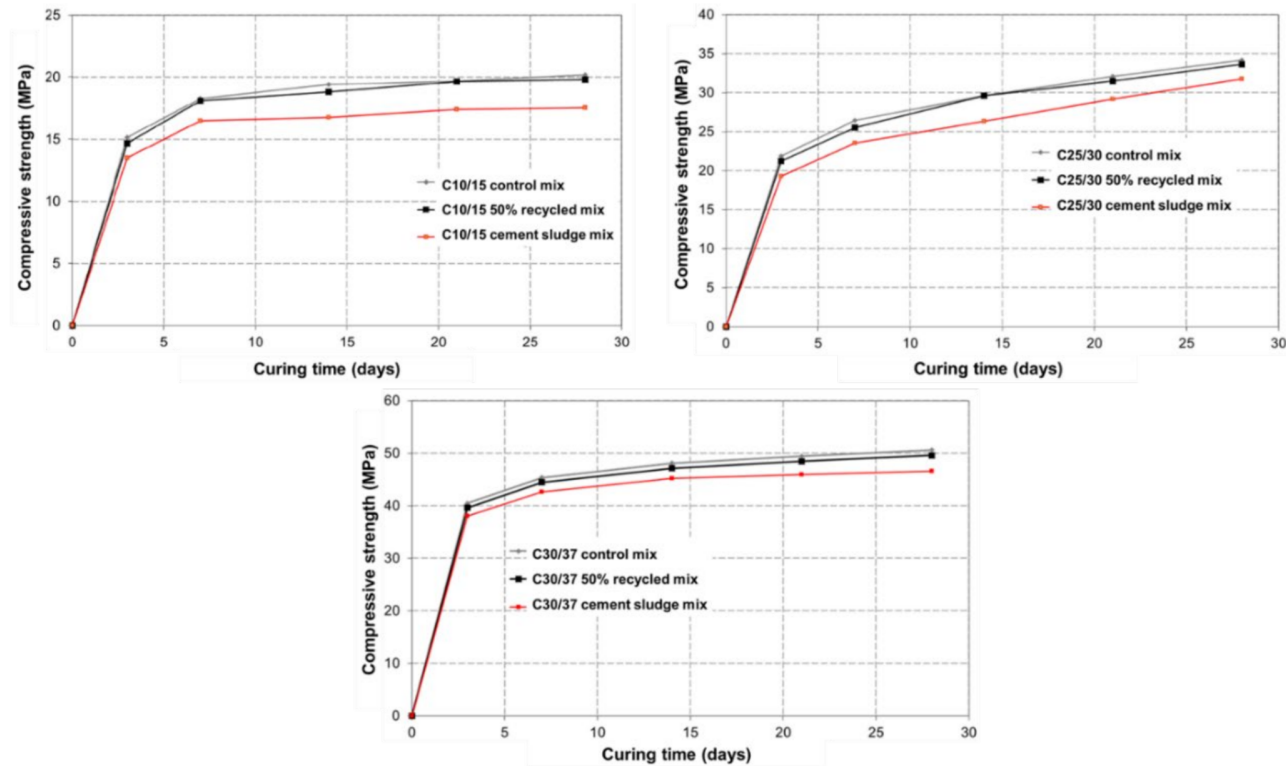

Figure 6. Compressive strength of concretes made with recycled and natural products.

The results show that, regardless of the concrete grade, the control mixture and the $50 \%$ recycled mixture reached similar compressive strength values at 28 curing days, with a slight decrease of $2 \%$ for all the concrete classes analyzed. This reduction can be associated with the presence of microfiltered water, which, compared to the control water, involves a slight decrease in terms of compressive strength of the mixtures, as previously demonstrated. In fact, Table 6 highlights that the use of microfiltered water allows to reach compressive strength values equal to $98 \%$ of the compressive strength provided by samples manufactured with control water. The authors Coppola et al. [27], obtained similar results, as concretes made with recycled water obtained through a sedimentation process showed a slight reduction in compressive strength. Despite this, the results confirm what was stated by Ferrari et al., 2014 [22]. The authors highlighted that concrete made with recycled aggregates recovered from returned concrete in partial substitution for natural aggregates ( $30 \%$ by weight) has similar compressive strength to reference concrete. Obla et al. [21] recorded a reduction in resistance in the range of $3-22 \%$. However, this decrease is not substantial, and the strength drop can be compensated for by normal mixture adjustments to achieve the desired strength.

At the same time, the mixture with cement sludge as filler generally shows a decrease in compressive strength of about $15 \%$ for $\mathrm{C} 10 / 15$ concrete grade and $7 \%$ for $\mathrm{C} 25 / 30$ and 
C30/37 concrete grade. As stated by Obla et al. [21], this is mainly due to the higher presence of fine particles, which have higher water absorption values.

From these data, it is possible to state that all the products obtained from the treatment of the returned concrete (aggregates, washing water and cement sludge) can be used for concrete production. In particular, the combined use of recycled aggregates and microfiltered water guarantees mechanical performance similar to that of a traditional concrete. Similarly, the use of cement sludge as filler (partial substitute of the natural aggregate fine fraction) allows to obtain concrete mixtures with good mechanical performance. This is demonstrated by the fact that at 28 curing days, all the mixtures guaranteed mechanical performance higher than the desired design strength.

\subsubsection{Hygrometric Shrinkage}

The hygrometric shrinkage tests were carried out according to UNI EN 11307. Figure 7 shows the trend over time of the sample's deformation induced by the hygrometric shrinkage. In particular, the reported values refer to the average of the two measurements relating to the opposite faces of each sample. For concrete C10/15, the shrinkage deformation after 28 curing days ranged between $220 \mu \mathrm{m} / \mathrm{m}$ and $260 \mu \mathrm{m} / \mathrm{m}$, while for C25/30 and C30/37 concrete grades, the values ranged between $230 \mu \mathrm{m} / \mathrm{m}$ and $300 \mu \mathrm{m} / \mathrm{m}$ and between $220 \mu \mathrm{m} / \mathrm{m}$ and $270 \mu \mathrm{m} / \mathrm{m}$, respectively. Generally, when compared to a traditional concrete, the recycled aggregate and cement sludge mixtures have higher shrinkage.

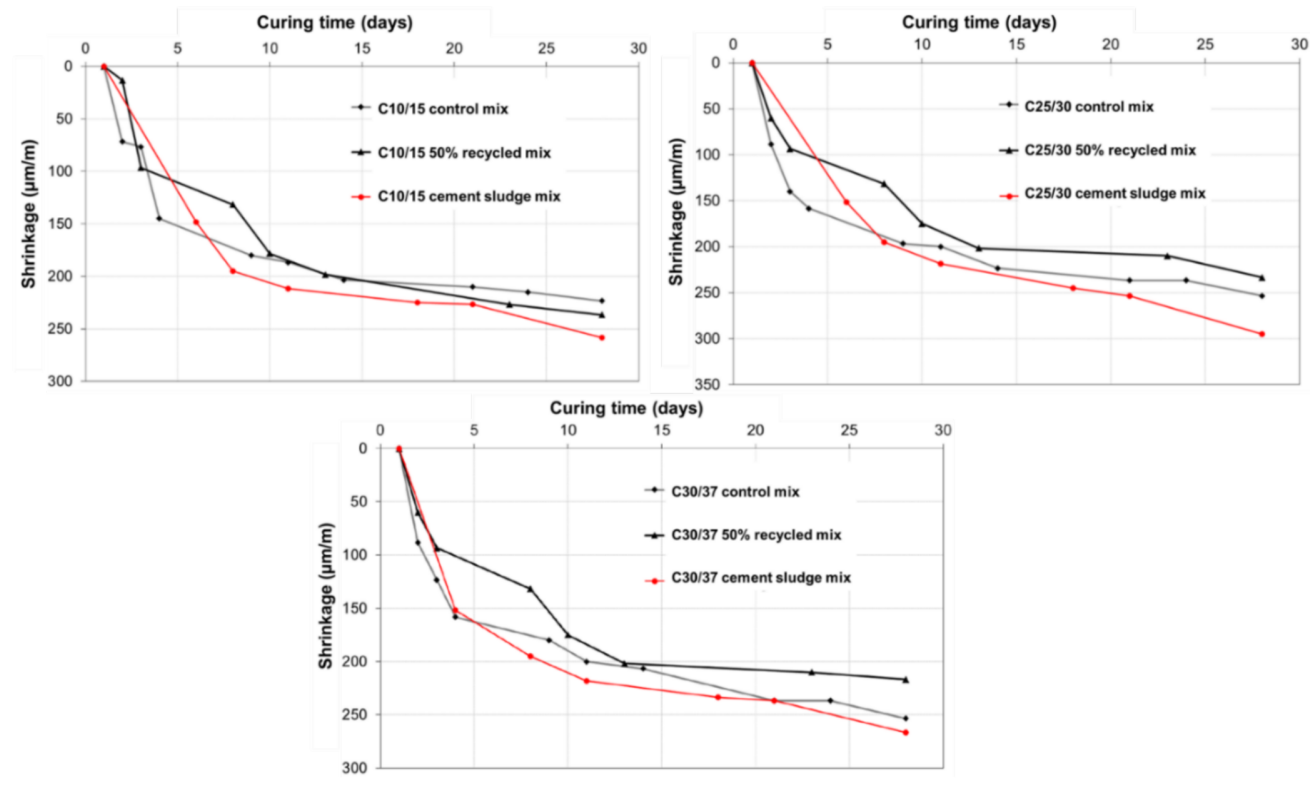

Figure 7. Hygrometric shrinkage of concrete samples at different curing days.

According to Chatveera et al. [32], this is mainly due to the fact that the washing water and the cement sludge yields more capillary pores compared to the normal concrete as a consequence of the dissolution of unstable ettringite. In particular, the interstitial water gradually migrates to the atmosphere, causing higher shrinkage.

\section{Concluding Remarks}

In this paper, a new technology for the treatment of fresh returned concrete is presented. In particular, by means of a mechanical system equipped with buffer and Archimedes screws, it is possible to separate and recover fine $(\mathrm{d} \leq 5 \mathrm{~mm})$ and coarse $(\mathrm{d} \geq 5 \mathrm{~mm})$ recycled aggregates. At the same time, the water coming from the washing process is sent to a microfiltration process, where a filter membrane separates the liquid phase (microfiltered water) from the solid phase (cement sludge). To guarantee the quality of the output materials, no type of potentially toxic additive is added. 
In this context, the main aim of the study was to investigate the technical and environmental feasibility of using these products as new materials for concrete production. To achieve this goal, several experimental tests were carried out on fine and coarse recycled aggregates, microfiltered water, cement sludge and concrete mixtures.

Based on the experimental results, the following conclusions can be drawn.

- The fine and coarse recycled aggregates produced by the proposed technology comply with all the requirements imposed by UNI EN 12620 and, therefore, can be used for new concrete production. Similar to natural aggregates, they show density values in saturated-surface-dry conditions equal to $2720 \mathrm{~kg} / \mathrm{m}^{3}$ and a water absorption value of coarse recycled aggregates of $0.9 \%$. The presence of light organic impurities, radioactivity and alkali-silica reactivity was also not detected.

- In terms of environmental behavior, the recycled aggregates do not release any contaminants into the surrounding environment. In particular, the eluates produced fully comply with the regulatory limits established by M.D. 186/2006.

- Microfiltered water complies with all the chemical and mechanical requirements of UNI EN 1008 and can be used as new mixing water for concrete production.

- The cement sludge produced by the microfiltration process has a moisture content ranging between $53 \%$ and $61 \%$ and no longer has any hydration capacity. Therefore, it cannot be used as a partial substitute for Portland cement, but it can be used as filler in new concrete mixtures.

- Compared to the control concrete, the $50 \%$ recycled mixture reached similar compressive strength values at 28 curing days. Conversely, the cement sludge mixture generally showed a decrease in compressive strength of about $15 \%$ for $\mathrm{C} 10 / 15$ concrete grade and $7 \%$ for $\mathrm{C} 25 / 30$ and $\mathrm{C} 30 / 37$ concrete grade.

In conclusion, it is possible to state that, consistent with the principles of circular economy, the use of the products obtained by the proposed technology for concrete production is feasible and does not significantly affect the properties of the final concrete.

Author Contributions: Conceptualization, S.S., A.D., L.C. and G.P.; methodology, S.S., A.D. and L.C.; investigation, A.D. and L.C.; data curation, A.D. and L.C.; writing-original draft preparation, A.D.; writing - review and editing, A.D., L.C., S.S. and G.P.; supervision, S.S. and G.P.; project administration, S.S. and G.P. All authors have read and agreed to the published version of the manuscript.

Funding: This research received no external funding.

Institutional Review Board Statement: Not applicable.

Informed Consent Statement: Not applicable.

Data Availability Statement: Data sharing not applicable.

Acknowledgments: The authors wish to thank the company WAMGROUP ${ }^{\circledR}$ and its members for their willingness to supply the recycled materials (aggregates, washing water and cement sludge) necessary for the experimental tests, as well as for their operational and economic support to the research project development.

Conflicts of Interest: The authors declare no conflict of interest.

\section{References}

1. Federbeton. Rapporto di Sostenibilità; Federbeton: Rome, Italy, 2019.

2. ERMCO. Survey on Returned Concrete Management; European Ready Mixed Concrete Organization: Bruxelles, Belgio, 2016.

3. Ferrari, G.; Brocchi, A.; Squinzi, M.; Carbone, F.; Franceschi, V.; Zambianchi, P.A. Method for Producing Aggregates from Returned Concrete 2020. U.S. Patent 10875032B2, 29 December 2020.

4. Pacheco, J.; De Brito, J.; Jang, J.G.; Tulliani, J.-M. Recycled Aggregates Produced from Construction and Demolition Waste for Structural Concrete: Constituents, Properties and Production. Materials 2021, 14, 5748. [CrossRef] [PubMed]

5. Sulymon, N.; Ofuyatan, O.; Adeoye, O.; Olawale, S.; Busari, A.; Bamigboye, G.; Jolayemi, J. Engineering properties of concrete made from gravels obtained in Southwestern Nigeria. Cogent Eng. 2017, 4, 1295793. [CrossRef]

6. Bonoli, A.; Zanni, S.; Serrano-Bernardo, F. Sustainability in Building and Construction within the Framework of Circular Cities and European New Green Deal. The Contribution of Concrete Recycling. Sustainability 2021, 13, 2139. [CrossRef] 
7. Schmidt, M.; Spieth, H.; Haubach, C.; Kühne, C. Conservation of gravel resources-Concrete made with recycled aggregate. In 100 Pioneers in Efficient Resource Management; Springer Spektrum: Berlin/Heidelberg, Germany, 2019; pp. 234-237. [CrossRef]

8. Silva, R.V.; de Brito, J.; Dhir, R.K. Use of recycled aggregates arising from construction and demolition waste in new construction applications. J. Clean. Prod. 2019, 236, 117629. [CrossRef]

9. Verian, K.P.; Ashraf, W.; Cao, Y. Properties of recycled concrete aggregate and their influence in new concrete production. Resour. Conserv. Recycl. 2018, 133, 30-49. [CrossRef]

10. Pedro, D.; de Brito, J.; Evangelista, L. Structural concrete with simultaneous incorporation of fine and coarse recycled concrete aggregates: Mechanical, durability and long-term properties. Constr. Build. Mater. 2017, 154, 294-309. [CrossRef]

11. Diotti, A.; Plizzari, G.; Sorlini, S. Technical analysis of full-scale Construction and Demolition Waste treatment plants: Case studies of the Lombardy Region, Italy. Detritus 2021, 15, 51-66. [CrossRef]

12. Silva, R.V.; De Brito, J.; Dhir, R.K. Properties and composition of recycled aggregates from construction and demolition waste suitable for concrete production. Constr. Build. Mater. 2014, 65, 201-217. [CrossRef]

13. Park, S.; Wu, S.; Liu, Z.; Pyo, S. The Role of Supplementary Cementitious Materials (SCMs) in Ultra High Performance Concrete (UHPC): A Review. Materials 2021, 14, 1472. [CrossRef]

14. Juenger, M.C.G.; Siddique, R. Recent advances in understanding the role of supplementary cementitious materials in concrete Cem. Concr. Res. 2015, 78, 71-80. [CrossRef]

15. Yang, K.H.; Jung, Y.B.; Cho, M.S.; Tae, S.H. Effect of supplementary cementitious materials on reduction of $\mathrm{CO}_{2}$ emissions from concrete. J. Clean. Prod. 2015, 103, 774-783. [CrossRef]

16. Almutairi, A.L.; Tayeh, B.A.; Adesina, A.; Isleem, H.F.; Zeyad, A.M. Potential applications of geopolymer concrete in construction A review. Case Stud. Constr. Mater. 2021, 15, e00733. [CrossRef]

17. Xiao, R.; Jiang, X.; Wang, Y.; He, Q.; Huang, B. Experimental and Thermodynamic Study of Alkali-Activated Waste Glass and Calcium Sulfoaluminate Cement Blends: Shrinkage, Efflorescence Potential, and Phase Assemblages. J. Mater. Civ. Eng. 2021, 33, 04021312. [CrossRef]

18. Alabi, S.A.; Mahachi, J. Estimating the compressive strength of geopolymer recycled concrete. Mater. Today Proc. 2021, 43, 1973-1976. [CrossRef]

19. Hassan, A.; Arif, M.; Shariq, M. Use of geopolymer concrete for a cleaner and sustainable environment-A review of mechanical properties and microstructure. J. Clean. Prod. 2019, 223, 704-728. [CrossRef]

20. Gebremichael, N.N.; Karakouzian, M.; Jadidi, K. Investigation of setting time and compressive strength of ready-mixed concrete blended with returned fresh concrete. Constr. Build. Mater. 2019, 197, 428-435. [CrossRef]

21. Obla, K.; Kim, H.; Lobo, C. Crushed Returned Concrete as Aggregates for New Concrete Final Report. National Ready Mixed Concrete Association, 01649378. 2007. Available online: https://www.nrmca.org/wp-content/uploads/2020/06/CCA_Study_ Final_Report9-07 (accessed on 17 December 2021).

22. Ferrari, G.; Miyamoto, M.; Ferrari, A. New sustainable technology for recycling returned concrete. Constr. Build. Mater. 2014, 67, 353-359. [CrossRef]

23. Bester, J.; Kruger, D.; Miller, B. The use of a concrete additive to eliminate returned concrete waste volumes. MATEC Web Conf. 2017, 120, 03010. [CrossRef]

24. Wasserman, B. Wash Water in the Mix: Effects on the Compressive Strength of Concrete. Int. J. Constr. Educ. Res. 2012, 8, 301-316. [CrossRef]

25. Tsimas, S.; Zervaki, M. Reuse of waste water from ready-mixed concrete plants. Manag. Environ. Qual. Int. J. 2011, 22, 7-17. [CrossRef]

26. Férriz-Papia, J.A. Recycling of fresh concrete exceeding and wash water in concrete mixing plants. Mater. Constr. 2014, 64, e004. [CrossRef]

27. Coppola, L.; Lorenzi, S.; Pellegrini, S. Rheological And Mechanical Performances Of Concrete Manufactured By Using Washing Water Of Concrete Mixing Transport Trucks. Spec. Publ. 2015, 305, 32.1-32.12.

28. Asadollahfardi, G.; Asadi, M.; Jafari, H.; Moradi, A.; Asadollahfardi, R. Experimental and statistical studies of using wash water from ready-mix concrete trucks and a batching plant in the production of fresh concrete. Constr. Build. Mater. 2015, 98, 305-314. [CrossRef]

29. Ekolu, S.; Dawneerangen, A. Evaluation of recycled water recovered from a ready-mix concrete plant for reuse in concrete. undefined 2010, 52, 77-82.

30. Anastasiou, E.; Papachristoforou, M.; Anesiadis, D.; Zafeiridis, K.; Tsardaka, E.-C. Investigation of the Use of Recycled Concrete Aggregates Originating from a Single Ready-Mix Concrete Plant. Appl. Sci. 2018, 8, 2149. [CrossRef]

31. Quattrone, M.; Angulo, S.C.; John, V.M. Energy and $\mathrm{CO}_{2}$ from high performance recycled aggregate production. Resour. Conserv. Recycl. 2014, 90, 21-33. [CrossRef]

32. Chatveera, B.; Lertwattanaruk, P.; Makul, N. Effect of sludge water from ready-mixed concrete plant on properties and durability of concrete. Cem. Concr. Compos. 2006, 28, 441-450. [CrossRef]

33. Su, N.; Miao, B.; Liu, F.S. Effect of wash water and underground water on properties of concrete. Cem. Concr. Res. 2002, 32, 777-782. [CrossRef] 